\title{
Affymetrix loses first round of patent battle
}

London

An eminent Oxford professor has won the first round of a bitter battle with a California-based company that makes 'microarray' technology, used to determine which genes in a cell are switched on. Ed Southern claims that Affymetrix is trying to use its patents to exert a "stranglehold" over the development of the technology.

A British judge ruled last week that Affymetrix did not have the right to use techniques developed by Southern, perhaps best known as the inventor of the eponymous 'Southern blot' used for isolating and identifying DNA sequences.

Affymetrix had argued that it had acquired a license to basic microarray techniques patented by Southern in 1999, when it bought the microarray activities of Beckman Coulter, Inc. - which had entered into an earlier licensing agreement with the company Oxford Gene Technology (OGT), set up by Southern and the University of Oxford in 1995.

But the judge ruled that, despite its active research programme, Beckman Coulter did not have any products - and could not therefore be considered to be a 'business' in a way that would have allowed Affymetrix to claim the rights to its licenses.

OGT officials say that their dispute with Affymetrix originated in Southern's commitment to licensing microarray technology in a way that gives competing research teams the freedom to develop rival techniques.

Southern says that he respects the work of Affymetrix's scientists. "But through their patents they are claiming rights over things that they did not invent, or that are not patentable."

The dispute over the transfer of the Beckman Coulter license follows the earlier breakdown of negotiations between Affymetrix and OGT. Chris Shelley of the Oxford company says that this was partly because of Affymetrix's refusal to allow OGT access to some of its own patents as part of a crosslicensing deal.

Last week's ruling will have a major impact on a broader case that is due to go to trial this October in a federal court in Delaware. In this, OGT is claiming that Affymetrix has infringed its patents in developing its so-called GeneChip technology. Affymetrix is responding by claiming that OGT's patents are invalid.

\section{UK ethicists back use of stem cells}

\section{London}

British researchers are a step closer to working on human embyronic stem cells, following last week's endorsement of such research by the country's main bioethics panel, the Nuffield Council on Bioethics.

The endorsement coincides with press reports that an advisory panel set up by the British government last summer under its chief medical officer, Liam Donaldson, is also about to propose giving such experiments the green light.

Such a move would need parliamentary approval, as it would require the amendment of the regulations

implementing the Human Fertilization and Embryo Act of 1990. These allow research on embryos up to 14 days old, but only for a defined set of purposes - which do not currently include stem-cell research.

The parliamentary debate would inevitably be stormy. Lord Alton, who as a Liberal Democrat Member of Parliament was among the fiercest critics of the $\mathbf{1 9 9 0}$ act, wrote to The Daily Telegraph newspaper last week, describing the use of embryos to produce human 'spare parts' as "technological cannibalism".

But those in favour of a legislative amendment have generated a substantial body of support. This now includes the Nuffield panel, which states that "there are no grounds for making a moral distinction between research into diagnostic methods or reproduction which is permitted under UK legislation and research into potential therapies which is not permitted".

Martin Bobrow, a member of the panel and professor of clinical genetics at the University of Cambridge, says that "we felt the potential of this research is so great as to warrant an extension of the categories of research that are permitted". However, he adds that, given the number of 'spare embryos' currently left over from fertility treatments, "we do not see the need for the creation of embryos for research purposes".

The BioIndustry Association, which represents the country's biotechnology companies, also supports a change in the regulation. John Sime, its chief executive, argues that the wide range of diseases that might be amenable to therapies based on embryonic stem-cell research means that "most families in Britain" could benefit.

Government officials argue that, even after the Donaldson panel's advice is made public, the decision on whether to amend the legislation should be left to the outcome of the parliamentary discussion.

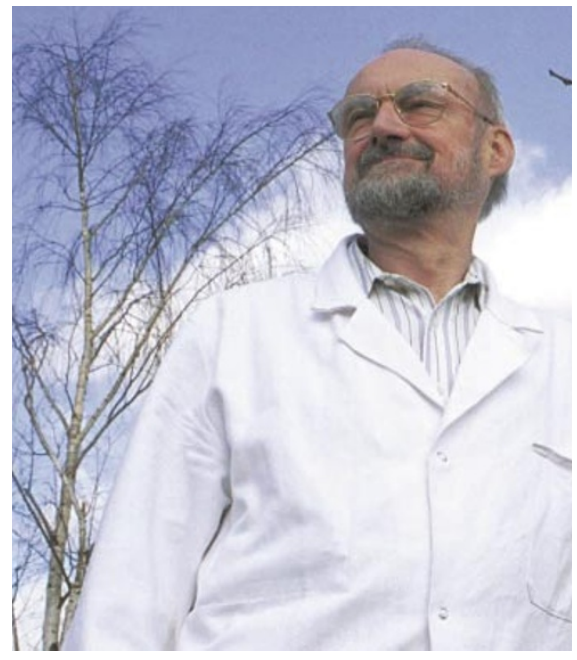

Southern: Affymetrix's scientists are "claiming rights over things that they did not invent".

The British company is also trying to get Affymetrix's British and European patents revoked. "The main basis of these actions is that Affymetrix's patents are unduly broad, covering areas of microarray technology that they cannot validly claim to have invented," say OGT officials.

Until now, Affymetrix's first line of defence against the charge of infringing OGT's patents was that its purchase of Beckman Coulter's 'business' gave it the right to use the OGT technology. The British judge's ruling, which is also valid in the United States, shoots down this argument.

OGT officials say that if their suit is successful, they will press for damages which based on Affymetrix's sales figures - have been estimated at up to US\$300 million. Affymetrix officials last Friday defended their position, pointing out that the British ruling still left OGT having to defend its patents in the US and European courts.

"OGT will need to overcome significant flaws in their patents," says Vern Norviel, senior vice-president and general counsel of Affymetrix. "As the problems with OGT patents are exposed, we are highly confident that Affymetrix will prevail."

Norviel says that Affymetrix has "the strongest DNA patent portfolio in the field", with more than 70 patents issued and several hundred applications pending. "The ruling has no impact on Affymetrix's commanding intellectual property estate," he says.

Investors are hedging their bets. Some stock analysts are backing Affymetrix's confidence that it will be able to defend its strong patent position, but others are less optimistic. Last Friday, when most biotechnology stocks were rising, news of the British judgement sent Affymetrix's share price on the New York Stock Exchange down from $\$ 143$ to $\$ 131$.

David Dickson 